\title{
MARIA MONTESSORI: AN INTELLECTUAL BIOGRAPHY
}

\author{
Anasuya Adhikari ${ }^{1}$, Dr. Birbal Saha ${ }^{2}$ * \\ ${ }^{I}$ Research Scholar, \\ ${ }^{2 *}$ Professor, \\ Department of Education, Sidho-Kanho-Birsha University, \\ Purulia, West Bengal, India
}

${ }^{*}$ Corresponding author: Dr. Birbal Saha

Professor, Department of Education, Sidho-Kanho-Birsha University, Purulia, West Bengal, India

Article DOI: $\underline{\text { https://doi.org/10.36713/epra8535 }}$

DOI No: $10.36713 /$ epra8535

\begin{abstract}
Maria Tecla Artemisia Montessori (August 31, 1870 - May 6, 1952), best known for her contribution to education and for the Philosophy of education that bears her name, was also a well-acclaimed science nurturer, psychiatrist, feminist and played an indispensable role in politics too. Montessori's career has been a mix and match of different role where she engaged herself besides imparting education. The efficacy of this paper would be to peek into Maria Montessori's career and inspect her role as a feminist, scientist, psychiatrist and study her social contributions. This paper is also an attempt and endeavour to seek into the relevance of Montessori today.

KEYWORDS: Montessori as A Scientist, Montessori as A Psychiatrist, Montessori as A Feminist, Montessori's Relevance Today
\end{abstract}

\section{INTRODUCTION}

Since the first public appearance of Maria Montessori, the feminist educator, in Berlin in 1896 to grace the event of the International Women's Conference, she was successful in gaining the engrossment of the press. It was not only her personality which was fascinating, but it was also her paper which was penned on the subject of female emancipation, added fame to her. She was a gifted orator and it made her way smooth into the public sphere. She gained publicity for her National League for the Care and Education of Mentally Deficient Children (1899). Her 'Case dei bambini' or Children's Houses was a path breaking innovation into the field of education. She also gained extraordinary success from her first book, The Montessori Method; Scientific Pedagogy as applied to Child Education in the Children's Houses (1912) and it focused her and her work to a much wider public domain. The book was written during 1909 while her stay at the villa of Leopoldo Franchettil in Citta di Castello. Her work instantly gained success and became famous within a decade and was translated into many languages.

\section{MONTESSORI AS A FEMINIST AND SCIENTIST}

Maria Montessori spent nearly two decades as a militant feminist speaker and continued with her managerial activity as director of her own institutions and an educationist. These two decades not only sing the saga of her colossal success all the more because they are related to the career and professional success of the second gender, but also track the growth of a phenomenal career: beginning from a psychiatrist to an educationist, to a university lecturer to the founder of new institutions.

From the historical point of view, very little has been read and explored about her and the 'method of scientific pedagogy'. scarcity of facts, 


\title{
EPRA International Journal of Research and Development (IJRD)
}

\author{
Volume: 6 | Issue: 9 | September 2021
}

- Peer Reviewed Journal

Inaccuracies and oversights has been the dominating reason which has obscured Montessori, or the 'woman of science'. Maria was born and brought up into an Italian society which offered very little or no scope to intellectual women willing to make a career. Arguably she hailed an international success in a discipline which deviated itself from her original training and hence the attentions were channelled and it took away to a greater extent her credentials as a scientist. Montessori was a militant advocator of women's emancipation and social medicine. She involved herself closely to positivist culture. Her works and activities were hailed by a profound secularism. Maria wanted to prove an important factor, freemasonry in the course of cultural diffusion of her method. Thereafter it was evident that she faced long and short term antagonism from both the Catholic and idealistic culture in Italy.

Maria's personal educational itinerary went through an unusual phase. In 1883 the technical institute of Reale Scuola Tecnica Michelangelo Buonarroti first allowed the entrance of women, and Montessori grabbed the opportunity to be a part of it. Montessori's next step was to pursue the medical degree from the university in 1890 . But what was more difficult than to study medical was to practice the same professionally. Hence, she enrolled herself into the two-year preliminary course in natural sciences and in 1892, she passed the exams and went on to take up the course in medicine,

It was very evident that the career of a woman professionally was not easy. But it was observed that the idea of resistance was much more theoretical than real. Therefore, Montessori's initial tryst with her study in 1892, she was the only female to graduate in medicine from Rome. Further she became the only lady in 1900 to enrol and attain a degree in medicine. L'Illustrazione Popolare published an inquiry in March 1896 which asked 'Can women be doctors?', with responses showing the existence of opposition were 'to the entry of women into the profession'. There has always been a reluctance to accept women as professionals. It becomes evident from the case of Anna Kuliscioff, the well known socialist, who was resented to take part in medical practice in 1887 at the Ospedale Maggiore in Milan.

\section{MONTESSORI AS A PSYCHIATRIST}

As a matter of fact, it becomes quite clear from the above given idea of the social structure that women were given access to very limited professional zones. Hence, while practising medicine was considered as a more masculine cult during those days, Montessori's firm decision to specialize in such another stream of psychiatry would definitely bring more resistance than ever. Psychiatry was considered to be more masculine than gynaecology or pediatrics. Montessori produced a thesis dealing with the subject of hallucinations, to invite more of 'examination of a theoretical controversy'. It would be apt to credit her success to appreciate, since out of 21,813 candidates of those who enlisted themselves to pursue a study at the university during the academic year, only 132 were women.

Montessori carefully dealt with the theory and experiments of the 'feeble-minded'. This again took itself into controversies and professionals from other disciplines took part into debating of who should be called into this category of feeble mindedness, how to determine the intensity of it and further provide support towards it. The active debates also included the economic and political role and question of who should look after the mentioned set of people for their betterment and positive growth.

\section{MONTESSORI'S PUBLIC APPEARANCES}

The feminist activities led by Montessori, brought her to public prominence. In 1896, Rome witnessed a formation of an association of women which indulged into 'infuse in women the spirit of solidarity and sisterhood'. It encouraged the women to go for their own interests. Montessori felt an immense need to come forward, since it was, innately been triggered by the then political events created because of the war in Africa and the reactions it produced from the other feminist groups. While in Milan and Turin, previously, feminists had already protested against the ruinous African war. The auspicious day of the event of the inauguration of the Roman group, the proclamation was read by the President. The newly-founded, Unione internazionale femminile per la pace or The International Women's Union for Peace, the banner of which carefully marked "the education of future generations belongs to mothers, calling upon sisters to work together, 'among women' and separately from men, towards universal disarmament." The very first action taken up by the Roman group was to unanimously vote and to send a message of support to the International Union of Peace in Paris. The message proposed to hold lectures on providing reading material for female workers, health and hygiene and the availability of a large collection of newspapers and magazines at the headquarters relating to the issues of women. Therefore, it contributed to the humble beginning of the Roman women's association where Maria Montessori devoted herself to the well being and promotion of other activities, expertised as a scientist. 


\title{
SJIF Impact Factor 2021: 8.013| ISI I.F.Value:1.241| Journal DOI: 10.36713/epra2016 \\ EPRA International Journal of Research and Development (IJRD)
}

\author{
Volume: 6 | Issue: 9 | September 2021
}

- Peer Reviewed Journal

Montessori never trod a smooth path. She met with a numerous resistance and criticisms which could never stop her from moving forward and spoke three times at the London meeting. Montessori spoke about the very poor working conditions of female school teachers and of the minors in Italy. "She spoke on behalf of Italian women about their understandable dissatisfaction with the laws that controlled the work of women; and she also made sure to refer to a problem that constituted a thorn in the heart of feminism in those years: the existence of an obstacle within the women's movement; It might justly be said that in Italy it is not so much man and the laws that are against the progress of woman as woman herself!... For example, she might belong to one the great charitable organizations; but the ladies limit themselves to collecting money at some great charity event, leaving the administration to men."

\section{MONTESSORI: THE INTERTWINING OF FEMINISM, MEDICINE AND POLITICS}

Maria Montessori's life was an admixture of medicine, education, feminism and politics. Following her participation and contribution to the International Feminist Congress in Berlin in 1896, the Italian newspapers wrote at length about her. After receiving an initial irritation from the mass and irritated by the fuss that aroused of the situation, she wrote to her parents, "My picture will never again appear in newspapers and nobody will again dare to poetize about my supposed charms." It was then when Montessori realised and decided to take full advantage of the press, using her beauty in promoting her causes. The photographs of Montessori which were most frequently used in the newspapers, were provided by her. The photographs portrayed Montessori in extraordinary dresses, carrying a book in her hand, with a fixed gaze towards her future. "Conscious of the impact of appearance she must have chosen that image of herself in order to promote a new model of woman. A few years later, in a scientific work on the anthropology of women, she herself made a symbolic reading of the graceful pose of a young woman of the Ciociaria area sitting next to her husband as an expression of female subordination." Her images projected: Elegance, culture and determination. Her images were a means to visualize her ideas and an active choice to adopt and spread her ideas.

The activities taken up by Montessori as a feminist, did not limit to the role assigned to the representative of Roman feminism. Her choices of life, education and profession she made during those years when society was not so progressive like today, must also be understood and credited under the perspective of her militant feminism. "Her work with 'degenerate' children and in defence of maternity must be seen in terms of the issues that were most pressing to the women's movement: the rights of the weak, and in particular the health of women and children. In this connection we should look a Montessori's importance as spokeswoman for the movement for the care and education of the mentally deficient."

\section{EPISTEMOLOGY}

The Montessori method of education is designed in such a way as to encourage and promote towards the growth of a child's natural inclination to be independent. The children in this environment are encouraged to explore on their own, and are placed in such an environment which is filled with opportunities for 'real work'. This challenges helps the children to carry out their everyday tasks with self-esteem and confidence. The Montessori method is based on routine work and consistency. The temper and tantrums showed by the learners can be avoided if there are consistency and predictability schedules. The Montessori materials are designed so, in order to be able to handle and encourage deep learning, promoting great academic skills.

\section{CONCLUSION}

Italian historical studies have dedicated very little attention to this phenomenal figure- a feminist, an educationalist, a scientist and a fighter of social cause. Maria Montessori can be credited for her extraordinary contribution and of unquestionable renown. She can aptly be called the Pantheon of pedagogy. The causes for the lack of interest on further research and studies on Maria Montessori is yet unknown. Not even the studies conducted on women's history and achievement showed generosity towards Montessori. Hence as a matter of fact, historical interest has definitely been inversely proportionate to her contribution to the world of science and education. Yet, Montessori's contribution to the world of education is undeniable.

\section{REFERENCES}

1. Adhikari, A. \& Saha, B. (2021). Rationalizing Maria Montessori's Teaching Methods in Global Contexts: 'When Education Met A Femme Reformatice, European Academic Research, Vol. IX, Issue- 2. May, pp.1431-1439.

2. Adhikari, A. \& Saha, B. (2021). Self-Nested Prison of Constraints: Feminism, Theory, Praxis and Beyond, International Journal of Research in Social Sciences, Vol. 11 Issue 08, August 2021, pp. 46 - 58. 
3. Babini, V. (2000). Science, Feminism and Education: The Early Work of Maria Montessori, Oxford Journals, Oxford University Press, Spring, pp. 44-67.

4. Cohen, S. (2015). The Montessori Movement in England, 1911-1952, Routledge.

5. Davies, S. (2019). The Montessori Toddler, Workman Publishing. New York.

6. Gutek, G. L. (Ed.). (2004). The Montessori Method; The Origins of An Educational Innovation: Including an Abridged and Annotated Edition of Maria Montessori's The Montessori Method, Rowman and Littlefield Publishers Inc.

7. International Council of Women. Report of Transactions of the Second quinquennial meeting held in London, July 1899, vol. I, Fisher Unwin, London, 1900, p. 257.

8. Isaacs, B. (2007). Bringing The Montessori Approach to Your Early Years Practice, Routledge.

9. Kramer, R. (1988). Maria Montessori: A Biography, Da Capo Press.

10. Lillard, A. S. (2005). Montessori The Science behind The Genius, Oxford University Press, Third Edition.

11. Montessori, M. (1964). Dr. Montessori's Own Handbook, Robert Bentley, Inc., Cambridge.

12. Montessori, M. (1947). Education For A New World, Kalakshetra, Adyar, Madras.

13. Montessori, M. (1915). My System of Education, House of Childhood Inc, New York.

14. Pitamic, M. (2004). Teach Me to Do It Myself, Barron's Publication, UK.

15. Seldin, T. (2017). How To Raise An Amazing Child The Montessori way, Dorling Kindersley Ltd., Second Edition.

16. Vallardi, M. (1910). Antropologia Pedagogica, (Montessori, Maria) pp. 230-1. (English Version) 